\title{
ASSESSMENT OF TRACE METALS CONTAMINATION ON SOIL FROM ABANDONED ARTISANAL TIN MINING PADDOCK IN BARKIN-LADI AREA OF PLATEAU STATE
}

Awuchi, Chibueze Gospel ${ }^{1}$; *Asoegwu, Chisom Rachael ${ }^{2}$; Nwosu, Oluchi Ulunma ${ }^{3}$; Nelson, Kalu, C. $\mathrm{T}^{4}$; Madumere, Chimaroke Christian ${ }^{5}$; Obunaonye, Chijindu Ogechi ${ }^{6}$; Nwobodo, Felicia Uzoamaka ${ }^{7}$; and Orji, Chimaroke Gabriel ${ }^{8}$.

${ }^{1,2}$ Department of Environmental Management, Federal University of Technology Owerri, Imo State, Nigeria;

${ }^{3}$ Department of Agriculture/Bioenvironmental Engineering, University of Agriculture and Environmental Sciences, Umuagwo, Imo State, Nigeria;

${ }^{4,5,6,7,8}$ Department of Environmental Management, Federal University of Technology Owerri, Imo State, Nigeria.

\begin{abstract}
The overwhelming rate of environmental degradation activated by the cruel mining operation associated with the unguided and incessant activities of artisans instigates this study. This study aimed at assessing the extents of trace metals contamination on soil resulting from the abandoned tin mining operation in Barkin Ladi Local Government Area of Plateau State. The abandoned mine site was delineated, and three samples were taken from the soil with respect to $0-15 \mathrm{~cm}$ and $16-30 \mathrm{~cm}$ horizontal depth. The three samples were tested and analyzed for heavy metals concentration such as $\mathrm{Pb}, \mathrm{Cr}, \mathrm{As}, \mathrm{Zn}, \mathrm{Cd}, \mathrm{Cu}$, and $\mathrm{Fe}$ at the Analytical Laboratory of the National Metallurgical Development Agency, Jos Nigeria. The result was subjected to the tolerable standard limit of the Federal Ministry of Environment for metals constituent in soil. Findings from the study reveal that the soil samples in both $0-15 \mathrm{~cm}$ and $16-30 \mathrm{~cm}$ depth show concentrations that were far above the limit set by the Federal Ministry of Environment of Nigeria for $\mathrm{Pb}, \mathrm{Cd}, \mathrm{Zn}, \mathrm{Cu}, \mathrm{Cr}$, and $\mathrm{Ar}$, with the exception of $\mathrm{Fe}$. The study recommends among others that; to ensure sustainable management of minerals with enforceable regulations in a sector dominated by stray mines, strengthening of current policy using command and control measures built on accountability and polluter pay principles to avert cases of dead trap and soil pollution as well as aesthetic destruction of the landscape is the way forward.
\end{abstract}

Keywords: Heavy Metals, Pollution, Mining, Contamination and Degradation. 


\section{INTRODUCTION}

The exploitation of mineral resources has unspecified key importance in the global sphere. In most part of the world, artisanal or small-scale mining (ASM) activities are at least as important as large-scale mining activities, particularly in terms of human socioeconomic development through creation of wealth (Acheampong, 2004), job creation (Hentschel et al., 2003), and as a mechanism for poverty alleviation and rural development (Hentschel et al., 2003). In poor rural region, mining represents the most promising, if not the only income opportunity available (Drechsler, 2001).

Notwithstanding the role of mining sector for income generation, employment, economic growth and development (Jerome 2003; Oelofse, et al., 2008), mining activities should not only be on the economic aspects, but on sustainable environmental management, which is part of the integrated global efforts for environmentally friendly production processes (Ajusa, 2003). The impacts that mines have on the environment are common, regardless of the scale of mining, but vary from mine to mine depending on some factors which may include type of minerals and technology used in the mining and processing of the minerals of interest (Herman and Kihampa, 2015).

Global recognition of mining activities as a potential threat to soil quality remains outstanding. Soil contamination with heavy metals as a global environmental problem is becoming increasingly important as industrialization, human population, and consumption pattern increase (Ogbonna and Okeke, 2011). In recent time, soils contaminated by metals from anthropogenic sources have received increasing attention (Chaw et al., 2007). In the European countries such as Bosnia, Croatia, Macedonia and Spain, additional contaminants and toxic compounds from mining activities have endangered the quality of surface and underground water by making it unsafe for drinking and industrial usage, disturbing the hydrology of the area (Roy, Roy, and Singh, 2003). According to Pulles et al. (2005), a main environmental challenge that is related to mining in many parts of the developing world is the unrestrained release of polluted water from abandoned mines (Commonly known as "Acid Mine Drainage (AMD)"). AMD does not only associate with water pollution, but it is also accountable for the degradation of soil quality, aquatic habitats and for allowing heavy metals to leach into the environment (Adler and Rascher, 2007).

In the African context, poverty coupled with poor strategic frameworks aimed to tackle mine closure and management, and the mining industry as whole, is a major threat to environmental sustainability (Oelofse, and Turton, 2008). With the increasing number of artisan's miners in Africa, estimate shows that in South Africa and Zambia, about 20\% of Agricultural land have been lost to contamination (Oelofse and Turton, 2008). The resultant effect of improper planning and negligence of regulations is the non-avoidance of appreciable amount of environmental degradation and ecological damage to soil associated to mining activities (Anirudha, 2005). Additionally, spill out and drips of harmful substances and the deposition of contaminated windblown air particulates can lead to soil pollution (Anirudha, 2005).

The adverse environmental impacts for artisanal mining are generally higher than those of other types of mining (Hentschel et al., 2003). The use of crude techniques and methods associated with artisanal mining operations makes it dirtier per unit of output than medium sized or large and current mining operations (Herman and Kihampa, 2015). This involves the production of large quantities of waste, which in most cases, account for more than $95 \%$ of ore mined as gangues (Adler, and Rascher, 2007). Most worrisome is the management of these 
gangues, especially in artisanal mines characterized by unsafe mining process and inadequate disposal technology (Herman and Kihampa, 2015). The impacts of this unsafe practice include; alteration of the soil structure, loss and overturning of the fertile top soil, air, soil and water pollution, instability of soil and rock masses, destruction of flora and fauna and noise pollution, as well as massive migration of animal species (Ojo and Adeyemi, 2003; Aigbedion and Iyayi, 2007; Adegboye, 2012).

In Nigeria, improved geological data over the years have revealed the abundance of numerous industrial, metallic, and non-metallic minerals like coal, tin, gold, marble, limestone, and others (National Bureau of Statistics, 2015). Mining activities in the country dated back as early as 1902, with tin ore being the first exploited mineral (Ministry of Mines and Steel Development, 2016). However, with an ongoing resurgence within the last decade, the mining sector accounts for $0.3 \%$ of national employment, $0.02 \%$ of exports and about 1.40 billion USD to the Nigerian GDP (Ministry of Mines and Steel Development, 2016). With how the petroleum industry has dominated the economy currently, informal mining operations and companies have become exceptionally dynamic in producing solid minerals in the absence of a well distinct policy, improved standards and improvements (Merem et al., 2017). This have been bolstered by the existence of 223 small-scale mining operations, 195 mining leases, 845 artisanal mining cooperatives and the 2,048 exploration licenses issued in the country (Musa, 2013). However, the mining industry is possibly, better known for its high environmental costs, poor health, and safety record. Seeing the recurrent hazards from thousands of abandoned mines across the country especially in Jos, Plateau State (Edun, 2013; Wapwera, 2005), and other risks in the sector, artisans mining activities have been linked to widespread ecological impacts at the expense of adjacent communities, as well as environmental externalities based on human nature interactions associated with mining such as lead poisoning, air, and soil and water pollution across Nigeria (Ashano, 2010).

For development to be sustainable 'mining inclusive,' it is argued that three dimensions: "economic development, social equity, and protection of the environment need to be balanced and addressed in unity. This was among the focus of the Sustainable Development Goals (SDG) adoption by the United Nations (UN) Member States in redressing the shortcomings in relation to the 2000-2015 "Millennium Development Goals (MDGs)" (Hofmann and Juergensen, 2017). However, mining activities have deteriorated the environment in several ways.

Over 1,100 to 4,000 tin and columbite mines abandoned after the mining boom of the $1960 \mathrm{~s}$ now pose severe health hazards to over 2 million residents in Plateau State. Most of the abandoned mines when flooded become traps of death capable of drowning citizens ignorant of the holes (Merem, et al., 2017). This has been made complex by exposing citizens to $325 \mathrm{~km}^{2}$ of polluted land attached with the presence of "carcinogenic radioactive materials and the littering of brain damaging mining wastes in the Jos area of Plateau State" (Edun, 2013; Wapwera, 2005; Faden, 2015).

Considering the level of damages done to the area from the past, there are now recurring dangers from radioactive mine tailings spread all over to people living around mining fields like Barkin-Ladi districts, which form the foci area of this study. The risks shoot from over a thousand mine ponds stretched all over abandoned mine fields along Jos area of Plateau State. The farce was distinguished by an apparently exploitative patronage by wealthy merchants of deprived artisanal miners who are illegally operating with unsafe procedures and having little or no considerations for environmental hazards. Most threatening is the introduction of heavy 
metals pollution in the pathways of soil and water, creating a very difficult situation for a healthy life (Verma and Gupta, 2011). The release of mining waste to the environment can result in weighty, generally irremediable destruction of environment. In most cases, the contaminated sites may never be fully restored, for the level of pollution is so persistent that there may not be any available remedy. To these effects, this study aims at assessing the extents of trace metals contamination on soil from abandoned tin mining paddock in Barkin-Ladi, Jos area of Plateau State, which will be achieved by delineating the various abandoned tin mining paddock areas in Barkin-Ladi LGA of Plateau State, collecting the soil samples from the mining sites for laboratory analysis, and determining the extent of soil contamination with heavy metals resulting from tin mining in the area.

Owing to the severe cases of environmental degradation ranging from landscape destruction, soil and water contamination, destruction of environmental aesthetic, loss of ecosystem and agricultural land associated to artisanal/small scale mining across the country, pragmatic steps must be taken to prevent/rehabilitate the existing abandoned mine site. The effect of mine closure on the environment is very dangerous owing to the environmental-human relationship. However, the availability of empirical research will provide better ways for managing mine site. Thus, findings from this study will be useful as the information from the study will unlock the mayhem resulting from the activities of artisanal mining of tin in Barkin-Lada, which will further be of help to both the Local Government and the State Government in the management of mining activities going on in the state. The recommendations from the study, when relied on and adopted appropriately, will help the Ministry of Mines and Steel Development as well as the Federal Ministry of Environment in Nigeria in carrying out favorable policies towards environmental protection. The findings from the study will also benefit the artisans by unveiling the dangers of their inappropriate activities and better ways to ameliorate future damages. Finally, the study will contribute to the existing body of literature regarding mining and its effect on soil resources.

\section{STUDY AREA}

\section{Geography of the Study Area}

Barkin-Ladi Local Government Area lies Northwest of Plateau State on a geographic point of $9^{\circ} 32^{\prime} 00^{\prime \prime} \mathrm{N} 8^{\circ} 54^{\prime} 00^{\prime \prime} \mathrm{E}$. It has an area of $1,032 \mathrm{~km}^{2}$ and a population of 175,267 at the 2006 census (Basil, 2014). The abandoned mine paddock is situated in Barakin Gangare District, at point $9^{\circ} 32.878^{\prime} \mathrm{N} ; 8^{\circ} 53.614^{\prime} \mathrm{E}$, covering about $1.5 \mathrm{~km}^{2}$.

\section{Climate of the Area}

The climate of the study area is typical of Jos-Plateau. "It is characterized by two distinct seasons; the dry and rainy seasons. The dry and the rainy seasons are usually very critical in determining the different types of features observed in the area. The dry season is characterized by lack of rainfall, low relative humidity, dry and dusty winds commonly called 'Harmattan.' This often results in poor visibility hence putting life to risk" (Yenne, 2004). "The dry season spans between November and March. However, for the past few years, this trend has drastically changed due to global warming".

The rainy season spans between April and October, and attains it peak towards the end of August. It is marked by heavy rainfall and high relative humidity. The heavy downpour may also reduce visibility but it is not as bad as that experienced during the dry season. The mean 
annual temperature ranges between $22^{\circ} \mathrm{C}$ to $27^{0} \mathrm{C}$ with the highest peak in April and the lowest in January. This temperature is very typical of high altitudes observed on the Plateau.

\section{Geology, Relief and Drainage}

The area lies within the basement complex rock formation. Its typical characteristics are the Younger Granites and intrusion of volcanic rocks covering most parts of the area. "The general geology of the area is predominantly underlain by banded gneiss" (Goki et al., 2010). The area falls within the immediate transition zone of the Jos Plateau uplifted area and the low land area in the eastern part of Plateau State. "The area is generally rugged and dominated by relief with elevations ranging from 500-700m above mean sea level. River Wase being the major drainage in the area is a father to a whole lot of streams and empties into the River Benue" (Peter et al., 2014).

\section{Soil and Vegetation}

The soil of the study area is conditioned by the geological parent rock. Generally, the soils are acidic (PH values mostly < 5.5) and lateritic (Ogunmola et al., 2014). The study area lies within the North of Guinea Savannah vegetation zone, which is an open woodland with tall grasses, extensively altered in recent time by human activities (Ogunmola et al., 2014).

\section{People and Economic Activities}

The area is predominantly habited by the Berom ethnic group and other speaking tribe such as Ryom, Hausa, as well as few Igbos and Yorubas whose major occupation are trading, farming and small scale mining (Blench et al., 2003). 


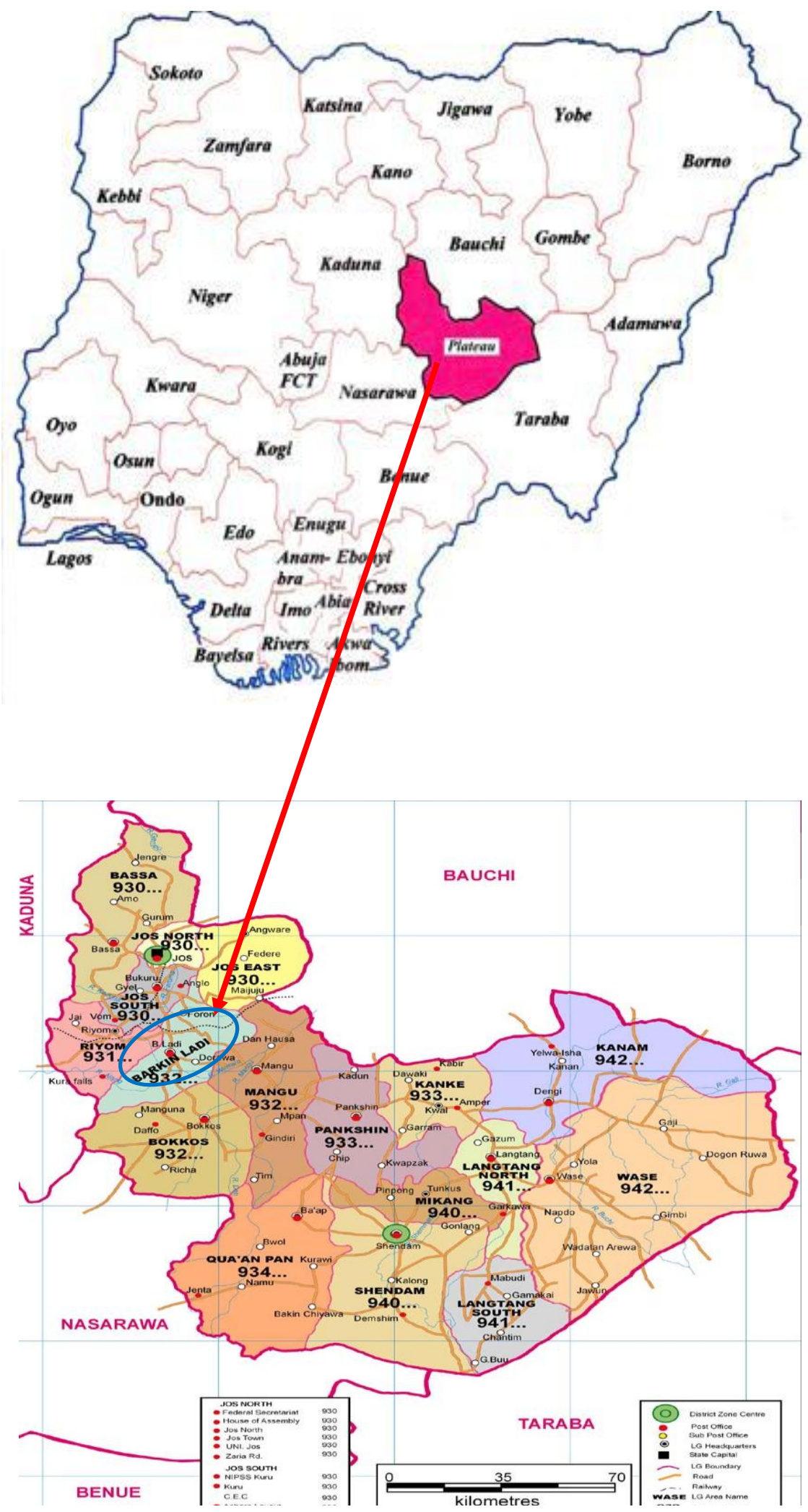

Figure 1: Map of Nigeria showing Plateau State in pink

Figure 2: Map of Plateau State showing Barkin Ladi the study area 


\section{MATERIALS AND METHOD}

\section{Reconnaissance Survey}

In carrying out this study, a reconnaissance survey of the study location was carried out in August 2019 to select the appropriate sites of investigation. Information collected during this survey aided the choice and mapping of the various abandoned mining site, and abandoned ponds for sampling.

\section{Field Work and laboratory Techniques}

The field exercise includes the identification of the point's location of the respective mine sites where the soil samples were collected. The exercise was aided by two field assistant. At the completion of the field sampling, the samples were taken to the laboratory for experimental analysis.

\section{Materials Used for Soil Sample Collection}

The basic materials and equipments used in conducting the field exercises are:

i. Cutlass

ii. Soil Auger

iii. Polythene bags

iv. Writable Adhesive tape

v. Marker

vi. Writing pad/pen

vii. GPS 60cx

viii. Laboratory based soil analytical equipments

\section{Procedure of Soil Sample Collection and Analysis}

Soil samples were representatively collected from three different points within the abandoned mine paddock. The soil samples (SS) collected were labeled SS1, SS2, and SS3. Due to homogeneity of the mining site, the soil samples were collected at two different depths, which were $0-15 \mathrm{~cm}$ and $16-30 \mathrm{~cm}$ with the use of soil auger. The choice of these depths is to help in ascertaining influence of tin mining on soil within average plant rooting depth as shown in the table 3.1 below.

\section{Table 3.1: Points of soil samples collection}

\begin{tabular}{|l|l|l|}
\hline Parameter & Latitude & Longitude \\
\hline SS1 & $9.548051^{\circ}$ & $8.894242^{\circ}$ \\
\hline SS2 & $9.547599^{\circ}$ & $8.893692^{\circ}$ \\
\hline SS3 & $9.548179^{\circ}$ & $8.893930^{\circ}$ \\
\hline
\end{tabular}

Source: Fieldwork, 2020. 


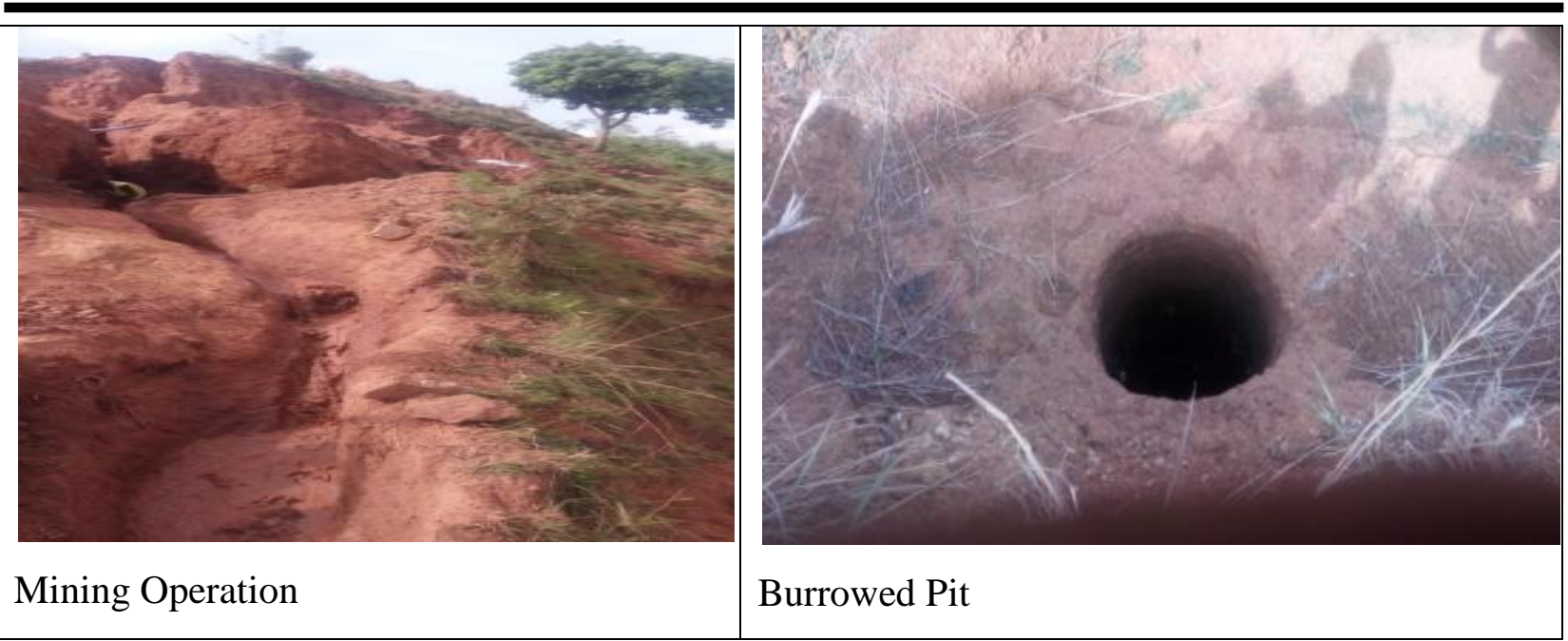

Source: Authors Survey (2018)

\section{Figure 3: Landscape of the Mine}

\section{Soil Sample Analysis}

The samples collected from the three sampling sites were put in a sterile polythene bags, sealed, marked and labeled, and transported to the laboratory within four hours of collection. At the laboratory, the soil samples were air dried, crushed, and allowed to pass through a $2 \mathrm{~mm}$ sieve. After air drying, one gram $(1 \mathrm{~g})$ was taken from each of the air-dried soil samples from depths of $0-15 \mathrm{~cm}$, and $16-30 \mathrm{~cm}$ which were then digested using $20 \mathrm{~cm}^{3}$ of $1: 1$ nitric acid and heated to boil until the volume reduced to $10 \mathrm{~cm}^{3}$ after which it was cool and filtered. The soil samples were digested using diethhylenetriamine pentacetic acid (DTPA) extraction procedures. This procedure was employed to obtain concentration of heavy metals and other physicochemical parameters considered to have potentials for soil contamination.

The result obtained of the analyzed soil samples were compared with the Federal Ministry of Environment soil physiochemical suitability for crop production and conclusion were made based on implication of results.

\section{RESULTS AND DISCUSSION}

The laboratory results of the sampled soil were subjected to comparison with the tolerable limit for soil quality as propounded by the Federal Ministry of Environment (FMEnv). This was in a bid to establish the extents of heavy metal contamination on soil resources at the artisanal mining area of Barki-Ladi, Jos.

\section{Analyzed Soil Results}

The nexus between metal and soil is such that when metal is introduced at the surface, downward transport will not happen to any extent, unless the retention capacity of the metal in the soil is stuffed or metal interactions with associated waste matrix enhances the mobility of the metal (McLean and Bledsoe, 1992). Under this condition, measurement of the totality concentration of metals in soils is effective for determining the vertical and horizontal degree of contamination and for increasing net change (leaching to groundwater and surface runoffs) in soil metal concentration over time (Daniel et al., 2014). Soil samples were collected from three points within abandoned mined paddock in the study area, and subjected to laboratory analysis with emphasis on plant root depth $(0-15 \mathrm{~cm}$ and $16-30 \mathrm{~cm})$ respectively. 
Article DOI: 10.46654/ij.24889849.e61112

Table 3.2: Results of Heavy Metals Concentration of Soil Samples Collected

\begin{tabular}{|c|c|c|c|c|c|c|}
\hline \multirow{3}{*}{ S/No } & \multirow{3}{*}{ Parameters } & \multicolumn{4}{|c|}{ Soil Analysis } & \multirow{3}{*}{$\begin{array}{c}\text { FMEnv } \\
\text { SL }\end{array}$} \\
\hline & & \multicolumn{4}{|c|}{ SS1 } & \\
\hline & & $0-15$ & Remark & $16-30$ & Remark & \\
\hline 1 & Lead & 3.167 & Not Tolerable & 2.142 & Not Tolerable & $1.5-2$ \\
\hline 2 & Chromium & 2.173 & Not Tolerable & 1.171 & Not Tolerable & 0.1 \\
\hline 3 & Arsenic & 1.105 & Not Tolerable & 1.010 & Not Tolerable & $<1$ \\
\hline 4 & Zinc & 3.10 & Not Tolerable & 2.15 & Not Tolerable & $<1$ \\
\hline 5 & Cadmium & 1.241 & Not Tolerable & 1.121 & Not Tolerable & 0.01 \\
\hline 6 & Copper & 1.612 & Not Tolerable & 1.608 & Not Tolerable & 0.1 \\
\hline 7 & Iron & 1.121 & Tolerable & 1.108 & Tolerable & 1.5 \\
\hline \multicolumn{7}{|c|}{ SS2 } \\
\hline 8 & Lead & 4.167 & Not Tolerable & 2.311 & Not Tolerable & $1.5-2$ \\
\hline 9 & Chromium & 1.172 & Not Tolerable & 1.051 & Not Tolerable & 0.1 \\
\hline 10 & Arsenic & 1.322 & Not Tolerable & 1.310 & Not Tolerable & $<1$ \\
\hline 11 & Zinc & 3.54 & Not Tolerable & 2.12 & Not Tolerable & $<1$ \\
\hline 12 & Cadmium & 1.519 & Not Tolerable & 1.402 & Not Tolerable & 0.01 \\
\hline 13 & Copper & 1.012 & Not Tolerable & 0.620 & Not Tolerable & 0.1 \\
\hline 14 & Iron & 1.018 & Tolerable & 0.818 & Tolerable & 1.5 \\
\hline \multicolumn{7}{|c|}{ SS3 } \\
\hline 15 & Lead & 2.107 & Not Tolerable & 2.100 & Not Tolerable & $1.5-2$ \\
\hline 16 & Chromium & 1.021 & Not Tolerable & 0.312 & Not Tolerable & 0.1 \\
\hline 17 & Arsenic & 1.304 & Not Tolerable & 1.211 & Not Tolerable & $<1$ \\
\hline 18 & Zinc & 2.210 & Not Tolerable & 1.312 & Not Tolerable & $<1$ \\
\hline 19 & Cadmium & 1.325 & Not Tolerable & 1.311 & Not Tolerable & 0.01 \\
\hline 20 & Copper & 1.010 & Not Tolerable & 0.401 & Not Tolerable & 0.1 \\
\hline 21 & Iron & 0.318 & Tolerable & 0.071 & Tolerable & 1.5 \\
\hline
\end{tabular}

Source: Researchers Survey (2020).

Note: SS= Soil Sample 
Outcome of the analysis shows that the concentration of $\mathrm{Pb}, \mathrm{Cr}, \mathrm{Ar}, \mathrm{Zn}, \mathrm{Cd}$ and $\mathrm{Cu}$ in the topsoil and subsoil in the three samples are distinctively above the FMEnv standard limit for metal concentration, with the exception of Fe. The topsoil and subsoil concentration of $\mathrm{Pb}$ is $3.167 \mathrm{mg} / \mathrm{L}, 2.142 \mathrm{mg} / \mathrm{L}$ in sample $(1), 4.167 \mathrm{mg} / \mathrm{L}, 2.311 \mathrm{mg} / \mathrm{L}$ in sample $(2)$, and $2.107 \mathrm{mg} / \mathrm{L}$, $2.100 \mathrm{mg} / \mathrm{L}$ in sample (3). The rate of $\mathrm{Pb}$ contamination in the soil is high as it significantly exceeds the Tolerable limit of $1.5-2 \mathrm{mg} / \mathrm{L}$ set by the FMEnv (Nigeria). The result shows that the concentration of $\mathrm{Pb}$ in the soils decreases vertically with increase in soil depth. $\mathrm{Pb}$ infected soil has the potential to result to uptake and accumulation in not poisonous plant parts with a resulting risk to human and animal health.

Topsoil and subsoil concentration of $\mathrm{Cr}$ across the three sampled soils is $2.173 \mathrm{mg} / \mathrm{L}, 1.171 \mathrm{mg} / \mathrm{L}$ in sample (1), $1.172 \mathrm{mg} / \mathrm{L}, 1.051 \mathrm{mg} / \mathrm{L}$ in sample (2), and $1.021 \mathrm{mg} / \mathrm{L} 0.312 \mathrm{mg} / \mathrm{L}$ in sample (3) respectively. While the $\mathrm{Cr}$ concentrations in all the sampling points are above the FMEnv tolerable limit across the soil horizon, the values in $\mathrm{Cr}$ concentration decrease with depth. According to Arun et al. (2005), "the exposure of plants to excess $\mathrm{Cr}$ have a metabolic alterations in plants either by a direct effect on enzymes or other metabolites or by its ability to generate reactive oxygen species, which may cause oxidative stress". The toxic effects of $\mathrm{Cr}$ on the growth of plant and development include modifications in the process of germination as well as in the growth of roots, trunks and leaves, which may affect total dry matter production and yield.

At a depth of $0-15 \mathrm{~cm}$, the Ar concentration in the three soil samples are $1.105 \mathrm{mg} / \mathrm{L}, 1.322 \mathrm{mg} / \mathrm{L}$, and $1.3041 \mathrm{mg} / \mathrm{L}$ respectively, while, the concentration decreases to $1.010 \mathrm{mg} / \mathrm{L}, 1.310 \mathrm{mg} / \mathrm{L}$ and $1.211 \mathrm{mg} / \mathrm{L}$ respectively at depth $16-30$. The results shows that the concentration of Ar in soils within the mined site are considerably high and exceeds the tolerable limit of FMEnv $(<1)$. Similar, the concentration of $\mathrm{Cd}$ across the sampling points were above the FMEnv tolerable limit of $0.01 \mathrm{mg} / \mathrm{L}$ at depth $0-15 \mathrm{~cm}(1.241 \mathrm{mg} / \mathrm{L}, 1.519 \mathrm{mg} / \mathrm{L}$ and $1.325 \mathrm{mg} / \mathrm{L})$ and $16-30 \mathrm{~cm}$ $(1.121 \mathrm{mg} / \mathrm{L}, 1.402 \mathrm{mg} / \mathrm{L}$ and $1.311 \mathrm{mg} / \mathrm{L})$. Both $\mathrm{Ar}$ and $\mathrm{Cd}$ are classified as Group 1 carcinogens by the International Agency for Research on Cancer (IARC). The human exposure to Cd or As either through drinking water or consumed through food has been associated with various cancers, principally kidney and lung for $\mathrm{Cd}$, and skin, lung, liver and bladder for $\mathrm{Ar}$ (Beyersmann and Hartwig, 2008). In trust with literature (Verbruggen et al., 2009), the concentration of $\mathrm{Cd}$ was much more bioavailable than $\mathrm{Ar}$ in the sampled soils. As a consequence, damaging effects on life in the environment and on human health are caused by these two elements in several ways, through the food chain (Keil et al., 2011). "Among the damages induced by $\mathrm{Ar}$ and $\mathrm{Cd}$ to living organisms, genome alteration is one of the most dangerous. Genomic instability is particularly related to cancer induction and progression in animals and to inhibition of growth and even to death in plants. In wild and agro ecosystems, the presence of genotoxic compounds significantly reduces the number of species and reduces the yield and quality of crops" (Nagajyoti et al., 2010; Liu, and Zhang, 2007)

$\mathrm{Zn}$ concentration in the three soil samples at depth $0-15 \mathrm{~cm}$ are $3.10 \mathrm{mg} / \mathrm{L}, 3.54 \mathrm{mg} / \mathrm{L}$, and $2.210 \mathrm{mg} / \mathrm{L}$ respectively. While at $16-30 \mathrm{~cm}, \mathrm{Zn}$ concentration in the three samples is $2.15 \mathrm{mg} / \mathrm{L}$, $2.12 \mathrm{mg} / \mathrm{L}$, and $1.312 \mathrm{mg} / \mathrm{L}$. The results are not in consonance to the tolerable limit of FMEnv $(<1)$. Likewise, the concentration of $\mathrm{Cu}$ at depth $0-15 \mathrm{~cm}$ in the three samples is $1.612 \mathrm{mg} / \mathrm{L}$, $1.012 \mathrm{mg} / \mathrm{L}, 1.010 \mathrm{mg} / \mathrm{L}$; and $1.608 \mathrm{mg} / \mathrm{L}, 0.620 \mathrm{mg} / \mathrm{L}, 0.401 \mathrm{mg} / \mathrm{L}$ at depth $16-30 \mathrm{~cm}$ respectively. $\mathrm{Cu}$ and $\mathrm{Zn}$ are together essential in the functioning of all living. While $\mathrm{Cu}$ element is necessary for photosynthesis and respiration processes in plants (Ashworth and Alloway, 2004). Zn plays an important role in catalyzing biochemical reactions by participating in the formation of an 
enzyme-substrate system, protein translation, gene copying and multiplication of a genetic chain (Sekler et al., 2007). Regardless the importance of both metals, excessive concentration of $\mathrm{Zn}$ is of great concern because of it toxicity to humans (stomach cramps, skin irritations, respiratory disorders), while excessive $\mathrm{Cu}$ reduced plant root length, root dry weight, total dry weight, root to shoot ratio amongst others (Zhang et al., 2010).

The concentration of Fe across the three sampled soils at depth $0-15 \mathrm{~cm}$ and $16-30 \mathrm{~cm}$ are $1.121 \mathrm{mg} / \mathrm{L}, 1.108 \mathrm{mg} / \mathrm{L}$ in sample $(1), 1.018 \mathrm{mg} / \mathrm{L}, 0.818 \mathrm{mg} / \mathrm{L}$ in sample (2) and $0.318 \mathrm{mg} / \mathrm{L}$, $0.071 \mathrm{mg} / \mathrm{L}$ in sample (3) respectively. While trace metals of Fe were detected across in the soils at both depth, the level of concentration of Fe were within the tolerable limit of the FMEnv (Nigeria).

Conclusively, the impact of artisanal mining operation in the study area has resulted to the release of heavy metals in considerable proportion above tolerable limit on the soil being the first receiving ends of the artisan's activities, with the exception of Fe. Heavy metals such as $\mathrm{Cu}, \mathrm{Fe}$, and $\mathrm{Zn}$ are essential micronutrients for animals and plants but may be dangerous at high levels, whereas $\mathrm{Cd}, \mathrm{Cr}, \mathrm{Pb}$, and $\mathrm{Ar}$ have no known physiological functions but are detrimental at certain limits (Nadal, and Domingo, 2004). In addition $\mathrm{Cr}, \mathrm{Cd}$ and $\mathrm{Ar}$ are carcinogenic, while $\mathrm{Pb}$ may cause neurological mutilation and malfunctioning of the central nervous system (Nadal et al., 2004).

\section{DESCRIPTIVE GRAPHS}
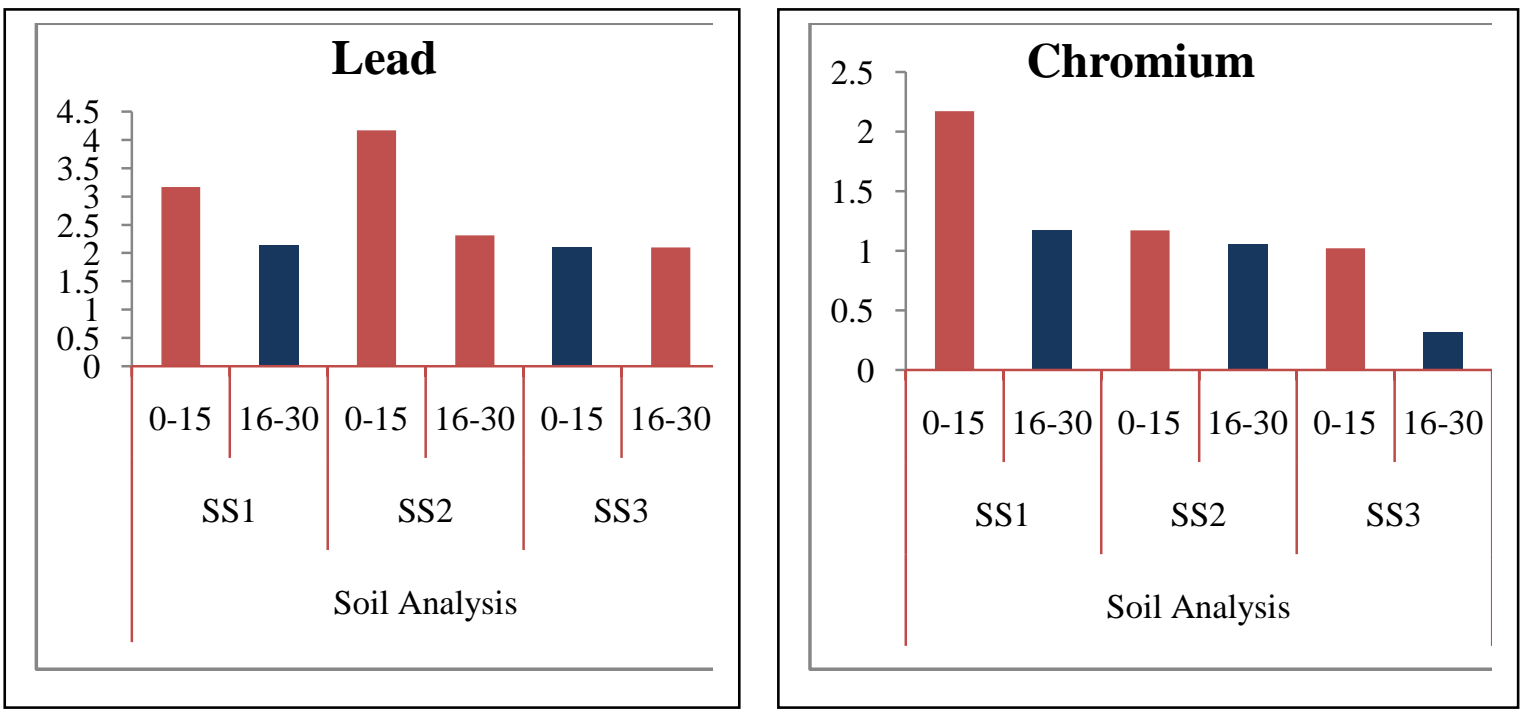

Figure 4: Spatial Variation in Lead and Chromium of the study location. 

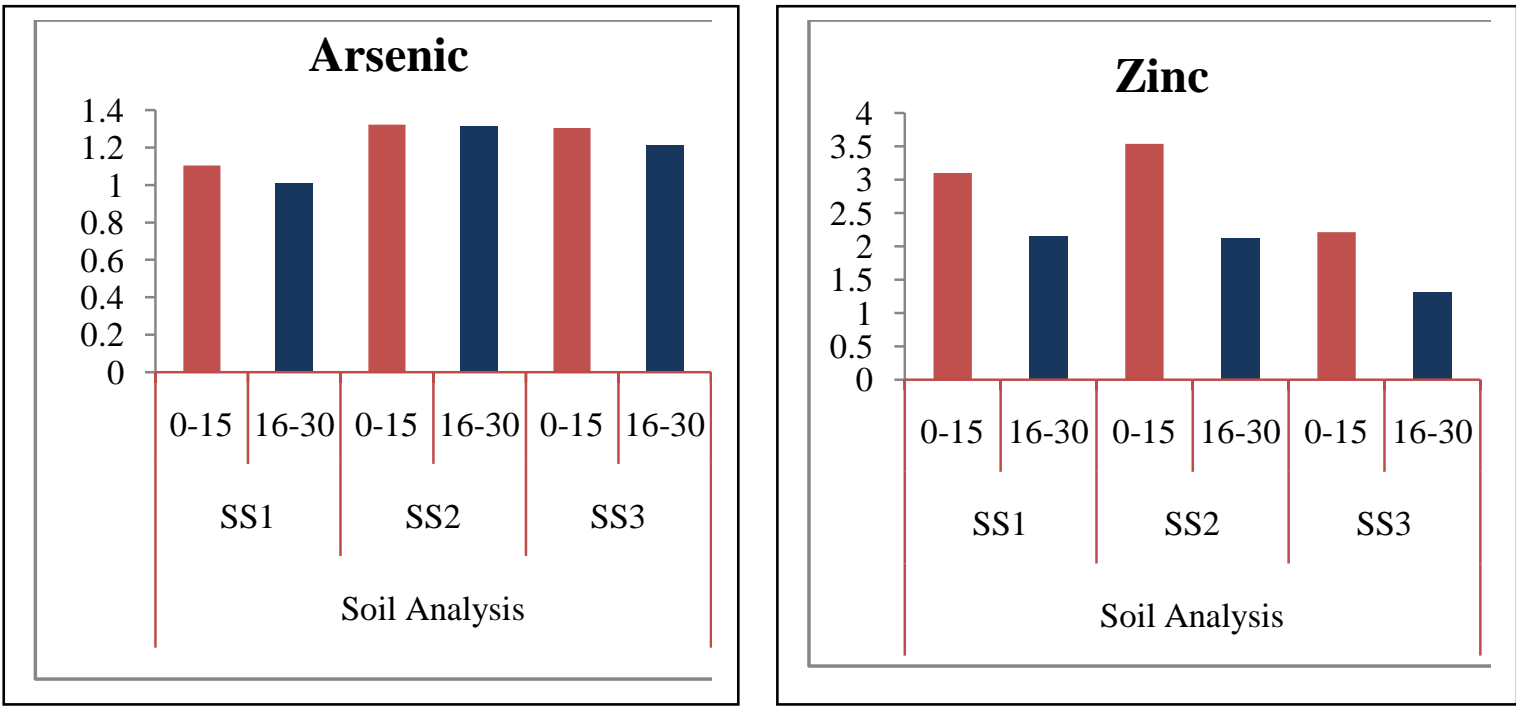

Figure 5: Spatial Variation in Arsenic and Zinc of the study location.
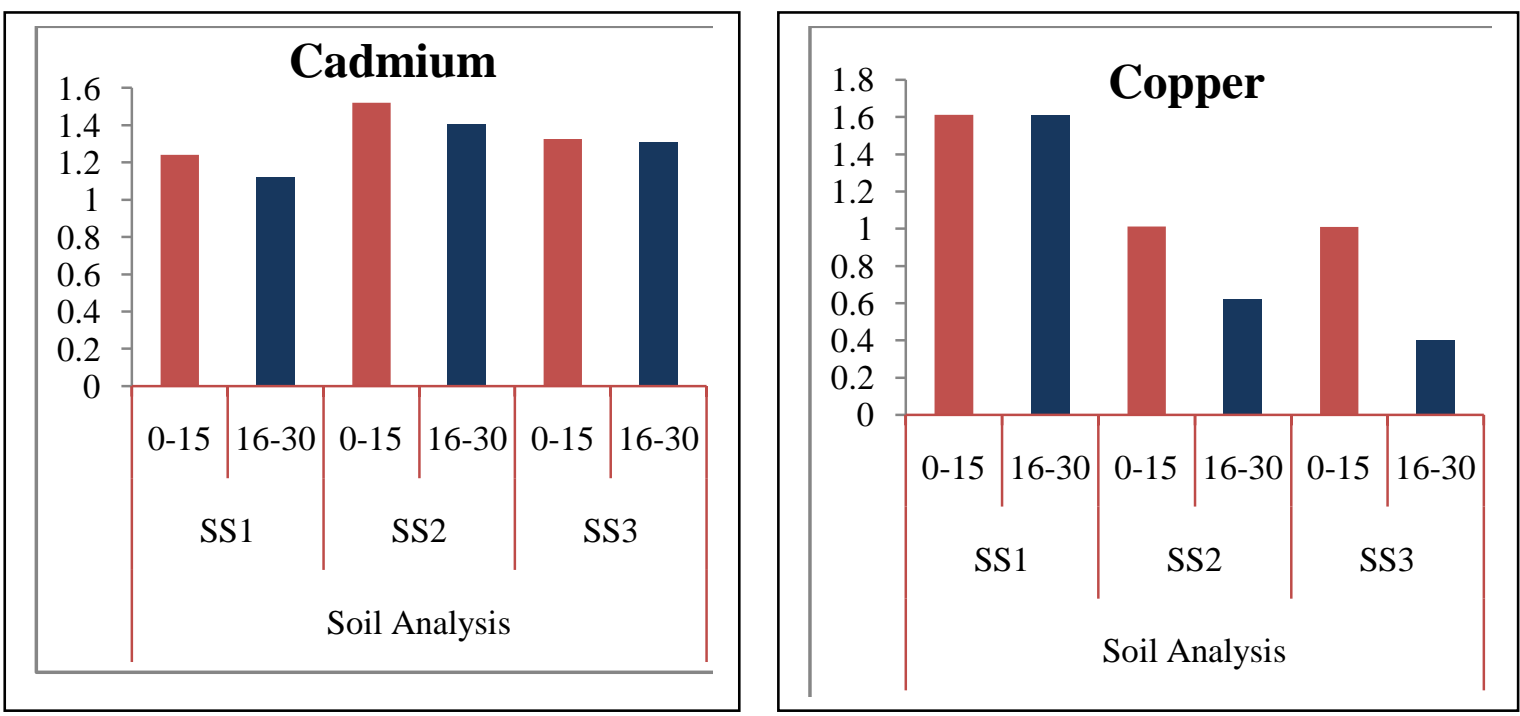

Figure 6: Spatial Variation in Cadmium and Copper of the study location. 


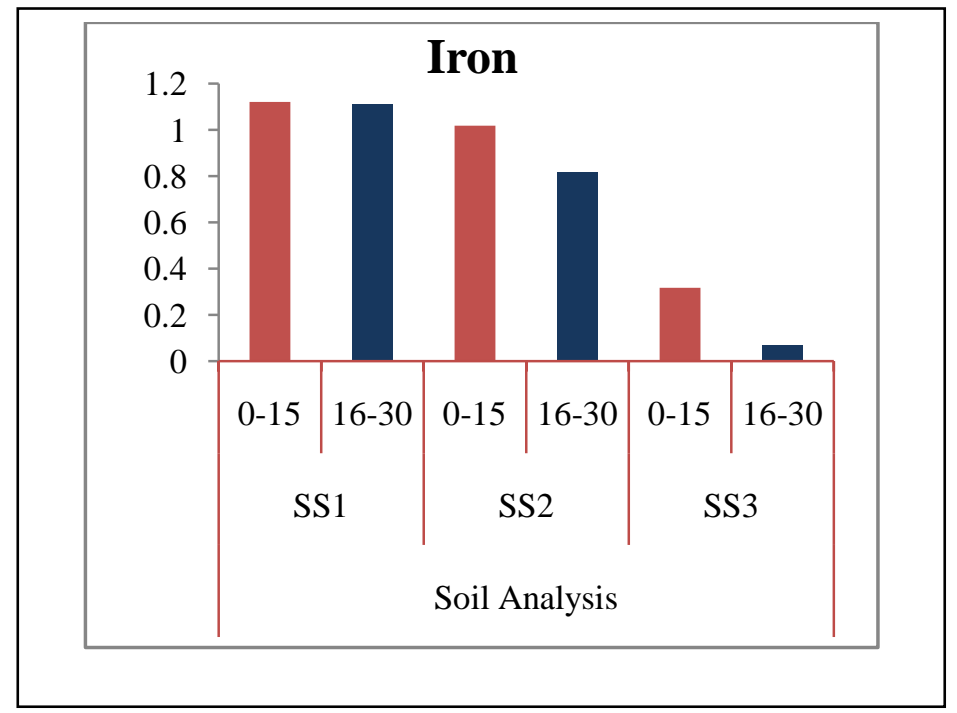

Figure 7: Spatial Variation in Iron of the study location.

\section{SUMMARY OF FINDINGS}

The increasing artisanal tin mining operation in Barkin-Lada Local Government Area of Plateau State has profoundly distorted the natural ecosystem of the place. This menace evolves over time starting from the pre-colonial era. In recent time, mining operation further gain momentum in the area following the current economic hardship and coupled with the government policy of diversification of the economy. To this fact, this research was carried out aiming to assess the extents of heavy metals concentration on soil resulting from abandoned tin mining paddocks in Barkin-Ladi Local Government Area of Plateau State.

The abandoned tin mining paddock in the study area was delineated, and samples of soil were collected and analyzed at the Analytical Laboratory of the National Metallurgical Development Agency, Jos Nigeria. The laboratory result was compared to ascertain the level of consonance of the concentrated metals to the standard limit set by the FMEnv (Nigeria). This was in accordance to the set assumption that: the abandoned artisanal mining of Tin at Barkin-Ladi in Plateau State, has no negative effect on heavy metal pollution of soil; the level of heavy metal concentration in soil at the abandoned artisanal tin mining site is within the standard limit for metal concentration in soil as set by the FMEnv (Nigeria).

Three soil samples collected within the abandoned mine site shows moderate concentration of $\mathrm{Fe}$, in consonance to the FMEnv standard limit at depth $0-15 \mathrm{~cm}$ and $16-30 \mathrm{~cm}$. However, $\mathrm{Pb}$ is $3.167 \mathrm{mg} / \mathrm{L}, 2.142 \mathrm{mg} / \mathrm{L}$ in sample $(1), 4.167 \mathrm{mg} / \mathrm{L}, 2.311 \mathrm{mg} / \mathrm{L}$ in sample $(2)$, and $2.107 \mathrm{mg} / \mathrm{L}$, $2.100 \mathrm{mg} / \mathrm{L}$ in sample (3) respectively for $0-15 \mathrm{~cm}$ and $16-30$ respectively. The values are far above the standard limit of the FMEnv $(1.5-2 \mathrm{mg} / \mathrm{L})$. At depth $0-15 \mathrm{~cm}$ and $16-30 \mathrm{~cm}$, the concentration of $\mathrm{Cr}$ across the three sampled soils is $2.173 \mathrm{mg} / \mathrm{L}, 1.171 \mathrm{mg} / \mathrm{L}$ in sample (1), 
$1.172 \mathrm{mg} / \mathrm{L}, 1.051 \mathrm{mg} / \mathrm{L}$ in sample $(2)$, and $1.021 \mathrm{mg} / \mathrm{L} 0.312 \mathrm{mg} / \mathrm{L}$ in sample (3) respectively. Similarly, the Ar concentration at depth $0-15 \mathrm{~cm}$ are $1.105 \mathrm{mg} / \mathrm{L}, 1.322 \mathrm{mg} / \mathrm{L}$, and $1.3041 \mathrm{mg} / \mathrm{L}$, while for depth $16-30 \mathrm{~cm}$, the concentration decreases to $1.010 \mathrm{mg} / \mathrm{L}, 1.310 \mathrm{mg} / \mathrm{L}$ and $1.211 \mathrm{mg} / \mathrm{L}$ respectively. The concentrations of both metals ( $\mathrm{Cr}$ and $\mathrm{Ar}$ ) are above the standard limit of FMEnv.

$\mathrm{Zn}$ concentration in the three soil samples at depth $0-15 \mathrm{~cm}$ are $3.10 \mathrm{mg} / \mathrm{L}, 3.54 \mathrm{mg} / \mathrm{L}$, and $2.210 \mathrm{mg} / \mathrm{L}$ respectively. While at $16-30 \mathrm{~cm}, \mathrm{Zn}$ concentration in the three samples is $2.15 \mathrm{mg} / \mathrm{L}$, $2.12 \mathrm{mg} / \mathrm{L}$, and $1.312 \mathrm{mg} / \mathrm{L}$. Likewise, the concentration of $\mathrm{Cu}$ at depth $0-15 \mathrm{~cm}$ in the three samples is $1.612 \mathrm{mg} / \mathrm{L}, 1.012 \mathrm{mg} / \mathrm{L}, 1.010 \mathrm{mg} / \mathrm{L}$; and $1.608 \mathrm{mg} / \mathrm{L}, 0.620 \mathrm{mg} / \mathrm{L}, 0.401 \mathrm{mg} / \mathrm{L}$ at depth $16-30 \mathrm{~cm}$ respectively. The concentration is far above the tolerable limit of FMEnv for $\mathrm{Zn}(<1)$ and $\mathrm{Cu}(0.1)$ respectively.

Concentration of $\mathrm{Cd}$ across in the sampled soils were above the FMEnv tolerable limit of $0.01 \mathrm{mg} / \mathrm{L}$ at depth $0-15 \mathrm{~cm}(1.241 \mathrm{mg} / \mathrm{L}, 1.519 \mathrm{mg} / \mathrm{L}$ and $1.325 \mathrm{mg} / \mathrm{L})$ and $16-30 \mathrm{~cm}(1.121 \mathrm{mg} / \mathrm{L}$, $1.402 \mathrm{mg} / \mathrm{L}$ and $1.311 \mathrm{mg} / \mathrm{L})$ respectively.

\section{CONCLUSION}

Based on the findings of the study, tin hunting in the study area is associated with increasing level of heavy metal pollution. Ecological problem of the artisanal mining operation as regards to heavy metals in the area is the pollution/contamination of soil within the mined site. Associated impact of the pollution of soil by heavy metals could manifest in poor crop yield, as well as food poisoning due to metal accumulation in cultivated crops, most especially vegetables.

\section{RECOMMENDATIONS}

The study recommends the following;

To ensure adequate handling of mineral ores under a awkward process full of work-related and ecological risks associated with artisanal and informal mining operation, devoid of permits and require specialized expertise, this study emphasizes on a loud call for compulsory education and social programs to ease the sufferings of those trapped in artisanal mining camps.

To ensure sustainable management of minerals with enforceable regulations in a sector dominated by stray mines, as a remedy, the study suggests the intensification of current policy using command and control measures built on accountability and polluter pay principles to avert cases of dead trap and soil pollution as well as aesthetic destruction of the landscape.

Government as the implementer should enhance local miners and integrates their activity by making funds available to them in the form of soft loans to either individuals or groups. 


\section{REFERENCES}

Acheampong, E. (2004). Impact Assessment of Mining activities by Ashanti Goldfields-Bibiani Limited on the Environment and Socio-economic Development of Bibiani. Unpublished undergraduate dissertation, Faculty of Social Sciences, Kwame Nkrumah University of Science and Technology, Ghana.

Adegboye M.A. 2012. Effect of Mining on Farming in Jos South Local Government Area of Plateau State. J. Soil Sci. Envrion. Manage. Vol 3: 77-83.

Adler, R., and Rascher, J., (2007). A Strategy for the Management of Acid Mine Drainage from Gold Mines in Gauteng. Report. No. CSIR/NRE/PW/ER/2007/0053/C. CSIR, Pretoria.

Aigbedion, I., and Iyayi S.E. (2007). Environmental effect of Mineral Exploitation in Nigeria. Int. J. Phys. Sci.2: 33-38.

Ajusa, J.A. (2003). Review of Refractory Ore Processes. A and B metallurgical consultants, Kwekwe, Zimbabwe.

Anirudha, S. (2005). Soil and Water Quality Monitoring In Opencast Mines. Unpublished thesis submitted to the Department of Mining EngineeringNational Institute of Technology Rourkela - 769008, India.

Arun, K.S., Carlos, C., Herminia, L., and Avudainayagam, S. (2005). Chromium Toxicity in Plants. Environment International Journal, 31739 - 753.

Ashano, E. (2010). The Effects of Mining on Water Quality and the Environment: The Case Study of Parts of the Jos Plateau, North Central Nigeria. The Pacific Journal of Science and Technology 11:1:631-639.

Ashworth, D.J., and Alloway, B.J. (2004). Soil Mobility of Sewage Sludge-derived Dissolved Organic Matter, Copper, Nickel and zinc. Environ. Pollut. Vol 127: 137-144.

Beyersmann, D. and Hartwig, A. (2008). Carcinogenic Metal Compounds: Recent insight into Molecular and Cellular Mechanisms. Arch Toxicol. Vol 82(8): pp 493-512.

Blench, RM., Daniel, P., and Hassan, U. (2003). Access Rights and Conflict over common Pool Resources in three States in Nigeria. Report to conflict Resolution Unit World Bank.

Chaw, W., Xiao-Chen, Z., Li, M., Per- fang, W., and Zhi-Young, G. (2007). Pb, Cu, Zn, and Ni in Vegetables in Relation to Extractable Fractions in Soil in Sub Urban areas of Nanjing, Chaina. Polish J. of Enviro. Stud. Vol 16(2): pp 199-207.

Drechsler, B. (2001). Small-Scale Mining and Sustainable Development within the SADC Region. MMSD, London.

Edun, E.O. (2013). Inventory of Abandoned Mine Ponds/Dams on the Jos-Bukuru NorthCentral Nigeria using G.I.S and Remote Sensing Technique. The International Journal of Engineering and Science IJES. Vol 2(5): 62-73. 
Faden, J. (2015). Jos a Century of Tin Exploration and Environmental Neglect. International Center for Investigative Reporting.

Goki, N.G., Ugodulunwa, F.X.O., Ogunmola, J.K., and Ogbole, J.O. (2010). Geological Controls for Groundwater Distribution in the Basement Rocks of Kanke, Central Nigeria from Geophysical and Remotely Sensed Data. African Journal of Basic \& applied Sciences. Vol 2(3-4): 104-110.

Hentschel, T., Hruschka, F., and Priester, M. (Projekt-Consult GmbH). (2003). Artisanal and Small-Scale Mining: Challenges and Opportunities. International Institute for Environment and Development and World Business Council for Sustainable Development. Russell Press Ltd, Nottingham, UK.

Herman, A. and Kihampa, C. (2015). Heavy Metals Contamination in Soils and Water in the Vicinity of Small Scale Gold Mines at Londoni and Sambaru, Singida Region, Tanzania. International Journal of Environmental Monitoring and Analysis. Vol. 3(6):pp. 397-403

Hofmann, U (GICHD), and Juergensen, O (UNDP). (2017). Leaving no one behind: Mine Action and the Sustainable Development Goals. GICHD - UNDP, Geneva.

Jerome, A. (2003). Preparation of Investment Profiles for Ventures in Mineral Resources. In: Elueze A.A. (ed.) Prospects for Investment in Mineral Resources of Southwestern Nigeria. Nig. Mining and Geosci. Soc. (NMGS), pp. 107-1103. ISBN 978-36831-0-1.

Keil, D.E., Berger-Ritchie, J., and McMillin, G.A. (2011). Testing for Toxic Elements: a focus on Arsenic, Cadmium, Lead, And Mercury. Lab Medicine. Vol 42: 735-742.

Liu, X.L., and Zhang, S.Z. (2007). Intraspecific differences in effects of co-contamination of Cadmium and Arsenate on early Seedling Growth and Metal uptake by Wheat. $J$ Environ Sci (China). Vol 19(10):1221-1228.

Mclean J.E. \& Bledsoe B.E. (1992). Groundwater Issue the behavior of Metals in Soils EPA.

Merem, E.C., Twumasi, Y., Wesley, J., Isokpehi, P., Shenge, M., Fageir, S., Crisler, M., Romorno, C., Hines, A., Hirse, G., Ochai, S., Leggett, S., and Nwagbos, E. (2017). Assessing the Ecological Effects of Mining in West Africa: The Case of Nigeria. International Journal of Mining Engineering and Mineral Processing. Vol 6(1): 1-19.

Ministry of Mines and Steel Development. (2016). Nigeria's Mining and Metal Sector Investment Promotion. Brochure August 2016.

Musa, M.S. (2013). Mid Term Report for the Minerals and Metals Sector. Ministry of Mines and Steel Development. Abuja, FCT: Ministry of Mines and Steel Development.

Nadal, M., Schuhmacher, M., and Domingo, J.L. (2004). Metal Pollution of Soils and Vegetation in an area with Petrochemical Industry. Sci Total Environ. Vol 321: 59-69.

Nadal, S. and Domingo, S. (2004). Aktar, Paramasivam, Ganguly, Purkait, Sengupta, 2010. 
Nagajyoti, P.C., Lee, KD., and Sreekanth, T.V.M. (2010). Heavy Metals, occurrence and Toxicity for Plants:A Review. Environ Chem Lett. Vol 8(3): 199-216

National Bureau of Statistics. (2015). Summary Report: Nigerian Mining and Quarrying Sector.

Oelofse, S., and Turton, A. (2008). Mine Water Pollution - Acid Mine Decant, Effluent and Treatment: A Consideration of Key Emerging Issues that may Impact the State Of The Environment. www.elsevier.com/locate/chemosphere.

Oelofse, S.H.H., Hobbs, P.J., Rascher, J. and Cobbing, J.E. (2008). The pollution and destruction threat of gold mining waste on the Witwatersrand: A West Rand case study. Symposium on Environmental Issues and Waste Management in Energy and Mineral Production (SWEMP 2007), 11-13 December 2007. Bangkok. Pp. 1-10.

Ogbonna, P.C. and Okeke, V.I. (2011). Metal content of Soil and Macronutrient of Gmelina Leave in Umuahia, Nigeria. Journal of Applied Sciences in Environmental Sanitation. Vol 6(1): pp 15-22.

Ogunmola, J.K, Gajere, E.N, Jeb, D.N, and Agene, I.J. (2014). Study of Land-cover Change in Yelwa-Barakin Gangare Area of Plateau State, North-Central Nigeria: A Geoinformatics Approach. The International Archives of the Photogrammetry, Remote Sensing, and Spatial Information Sciences. Vol XL-1.

Ojo, J.S. and Adeyemi, G.O. (2003). Opportunities for Ventures in Construction Materials. In: Elueze A.A. (ed.) Prospects for Investment in Mineral Resources of Southwestern Nigeria. Nig. Mining and Geosci. Soc. (NMGS). pp 47- 54. ISBN 978-36831-0-1.

Peter, J.S., Odubia, E.O., and Longpia, C.B. (2014). Relating Geology and Geological Structures with Regional Episodes: Implication for Groundwater Exploration and Development around Kwal-Kanke Area, Jos Plateau. International Journal of Engineering Research \& Technology (IJERT). Vol. 3(2): pp 571-575.

Pulles, W., Banister, S., and Van Biljon, M. (2005). The Development of Appropriate Procedures towards and after closure of Underground Gold Mines from a Water Management Perspective. Report No. 1215/1/05. Water Research Commission, Pretoria.

Sekler, I., Sensi, S.L., Hershfinkel, M., and Silverman, W.F. (2007). Mechanism and Regulation of cellular zinc transport. Mol. Med. Vol 13: 337-343.

Verbruggen, N., Hermans, C., and Schat, H. (2009). Mechanisms to Cope with Arsenic or Cadmium excess in Plants. Curr Opin Plant Biol. Vol 12(3):364-72.

Verma, DK., and Gupta, AP. (2011). Removal of Heavy Metals from whole Sphere by Plants working as Bioindicators - A Review. Basic Research Journal of Pharmaceutical Science. Vol 1(1): 1-7.

Wapwera, D. (2005). Abandoned Mines, Potential Home For The People, A Case Study of Jos Plateau. Journal of Civil Engineering and Architecture. Vol (9): 425-445. 
International Journal of Advanced Academic Research (Sciences, Technology and Engineering) | ISSN: 2488-9849

Journal DOI: 10.46654/ij.24889849

Vol. 6, Issue 11 (November, 2020)| www.ijaar.org

Article DOI: 10.46654/ij.24889849.e61112

Yenne, Y.E. (2004). The Geology and Ground Water Potentials of Vom-Kuru Area. Department of Geology and Mining, University of Jos.

Zhang, M.K., Liu, Z.Y., and Wang, H. (2010). "Use of single extraction methods to predict bioavailability of heavy metals in polluted soils to rice." Communications in Soil Science and Plant Analysis. Vol. 41(7) pp. 820-831. 